\title{
Neonatal outcomes in in vitro fertilization (IVF) pregnancies
}

\author{
Muhammad Buchori ${ }^{1,2^{*}}$, Suryono Yudha Patria', Tunjung Wibowo ${ }^{1}$, Ita Fauzia Hanoum ${ }^{3}$ \\ ${ }^{1}$ Department of Child Health, Faculty of Medicine, Universitas Gadjah Mada/Dr. \\ Sardjito General Hospital, Yogyakarta, ${ }^{2}$ Faculty of Medicine, Universitas Mulawarman, \\ Samarinda, ${ }^{3}$ Permata Hati Infertility Clinic, Dr. Sardjito General Hospital, Yogyakarta, \\ Indonesia.
}

DOI: http://dx.doi.org/10.19106/JMedSci005002201805

\begin{abstract}
In vitro fertilization (IVF) has been associated with poor neonatal outcomes. Preterm birth, small-for-gestational age (SGA), and low birth weight (LBW) rates are approximately twice as high in IVF pregnancies than in natural pregnancies. The IVF procedures have become more routine in recent years in Indonesia, but there have been few assessments of neonatal outcomes. The study aimed to evaluate the risk of preterm birth, SGA, and LBW in IVF infants. This was a retrospective cohort study performed in Dr. Sardjito General Hospital, Yogyakarta from January 2012 to December 2016. Pre-coded questionnaires were used to collect data from medical records. The relative risk of preterm birth, SGA, and LBW among IVF infants were calculated and compared to naturally conceived infants. A total sampling method was used for the IVF infants and a simple random sampling method was used for naturally conceived infants, who were born on the same day as an infant in the IVF group.

A total of 108 infants were recruited, consisting of 54 IVF infants and 54 naturally conceived infants. The IVF infants had increased risk of preterm birth $(R R=2.0 ; 95 \% \mathrm{Cl}$ $0.52-7.58)$ and $L B W(R R=1.25 ; 95 \% \mathrm{Cl} 0.53-2.92)$. However, the IVF infants did not have an increased risk of SGA (RR $=1.0 ; 95 \% \mathrm{Cl} 0.21-4.73$ ). In conclusion, the risk of preterm birth and LBW in IVF infants are higher than in naturally conceived infants, but not statistically significant. However, there is no increased risk of SGA in IVF infants.
\end{abstract}

\section{ABSTRAK}

Fertilisasi in vitro (FIV) dihubungkan dengan luaran neonatus yang rendah. Tingkat kelahiran preterm, bayi kecil untuk usia kehamilan, berat badan lahir rendah sekitar dua kali lebih tinggi pada kehamilan FIV dibandingkan kehamilan normal. Teknik FIV telah rutin dilakukn di Indonesia beberapa tahun belakangan ini, tetapi sedikit dilakukan penilaian terhadap luaran neonatusnya. Penelitian ini dilakukan bertujuan untuk mengkaji risiko kelahiran preterm, bayi kecil untuk usia kehamilan, berat badan lahir rendah pada anak dengan FIV. Penelitian ini merupakan penelitian kohort retrospektif yang dilakukan di RSUP Dr. Sardjito, Yogyakarta dari Januari 2012 sampai Desember 2016. Kuesioner berkode digunakan untuk mengumpulkan data dari rekam medik. Risiko relatif kelahiran preterm, bayi kecil untuk usia kehamilan, berat badan lahir rendah dihitung dan dibandingkan dengan bayi lahir normal. Metode sampling total digunakan untuk bayi dengan FIV dan metode sampling acak sederhana digunakan untuk bayi normal yang lahir pada hari yang sama. Total sebanyak 108 bayi direkrut yang terdiri dari 54 bayi dengan FIV dan 54 bayi normal. Fertilisasi in vitro meningkatkan risiko kelahiran preterm $(\mathrm{RR}=2,0 ; 95 \% \mathrm{Cl} 0,52$ $-7,58)$ dan berat badan lahir rendah $(R R=1,25 ; 95 \% \mathrm{Cl} 0.53-2,92)$. Namun demikian,

\footnotetext{
* corresponding author : mbuchori11@yahoo.com
} 
FIV tidak mempunyai risiko bayi kecil untuk usia kehamilan ( $\mathrm{RR}=1,0 ; 95 \% \mathrm{Cl} 0,21$ 4,73). Dapat disimpulkan, risiko kelahiran preterm dan berat badan lahir rendah pada FIV lebih tinggi daripada bayi normal, tetapi tidak berbeda nyata. Namun demikian, tidak ada kenaikan risiko terjadinya bayi kecil untuk usia kehamilan.

Keywords: in vitro fertilization - preterm - small for gestational age - low birth weight relative risk

\section{INTRODUCTION}

In vitro fertilization (IVF) is one of several assisted reproductive technologies (ART). The number of babies conceived through this procedure is increasing, with an estimated 3-5 million IVF babies worldwide. ${ }^{1-3}$ As the number of newborns increase, several studies have been conducted to evaluate neonatal outcomes of low birth weight (LBW), preterm birth, and small-for-gestational age (SGA). These outcomes occur almost twice as often compared to natural pregnancies, even in singleton IVF pregnancies. ${ }^{4-7}$ Guidelines provided, to optimize obstetrical management and counselling (counseling) of Canadian women using ART, and to identify areas specific to birth outcomes and ART requiring further research. Perinatal outcomes of ART pregnancies in subfertile women are compared with those of spontaneously conceived pregnancies. Perinatal outcomes are compared between different types of ART. This guideline discusses the adverse outcomes that have been recorded in association with ART, including obstetrical complications, adverse perinatal outcomes, multiple gestations, structural congenital abnormalities, chromosomal abnormalities, imprinting disorders, and childhood cancer. The Cochrane Library and MEDLINE were searched for English-language articles from 1990 to February 2005, relating to assisted reproduction and perinatal outcomes. Search terms included assisted reproduction, assisted reproductive technology, ovulation induction, intracytoplasmic sperm injection (ICSI Studies in Taiwan and India reported that the prevalence of preterm birth was increased in IVF pregnancies compared to natural pregnancies. $^{8,9}$

A study in eight infertility centers in Indonesia showed a pregnancy success rate of $29.46 \% .{ }^{10}$ In 2014, the IVF program at Dr. Sardjito General Hospital, Yogyakarta, had a $25.4 \%$ pregnancy success rate, while the percentage of live births was $19.8 \%$. These percentages increased in 2015 to $30.9 \%$ and $25.1 \%$, respectively. ${ }^{11,12}$ The IVF program in Indonesia has existed for approximately 29 years with an increasing percentage of live births, but the data on neonatal outcomes remains unclear. Hence, this study aimed to evaluate the risk of poor neonatal outcomes in IVF infants.

\section{MATERIALS AND METHODS}

\section{Subjects}

This retrospective cohort study was done from January 2012 to December 2016. Infants who were born at Dr. Sardjito General Hospital, Yogyakarta, through IVF pregnancies (IVF group) and natural pregnancies (natural group) were recruited as subjects. The infants whose mothers underwent IVF procedures outside this hospital and those whose medical records were not found or incomplete were excluded. The data were collected from medical records using questionnaires. 


\section{Protocol of study}

A total sampling method for IVF infants and a simple random sampling method for the natural group were used. Naturally conceived infants born on the same day as an IVF infant underwent simple random sampling for inclusion. If no naturally conceived infant was found on the same dayas an IVF infant, retrieval was extended to up to three days later.

A minimum of 64 subjects was required for each group to obtain $90 \%$ power with $5 \%$ significance level. In this study, dependent variables were neonatal outcomes, i.e., birth weight, gestational age, and birth weight according to gestational age, while independent variables were the process of fertilization (IVF/ natural). Confounding variables were maternal age, parity, and placental abnormalities.

The definition of LBW was weight at birth of less than 2,500 g, regardless of the gestational age; the definition of SGA was birth weight according to gestational age of less than $10^{\text {th }}$ percentile on the Lubchenco curve. Gestational age was defined as the length of pregnancy until the time of delivery. By the Dubowitz score, preterm was defined as $<37$ weeks gestational age. ${ }^{13}$ Maternal age was defined as the age of the mother at the time of delivery. Parity was defined as the number of previous pregnancies that reached viable gestational age. Placental abnormalities included placental abruptio or placenta previa. Faculty of Medicine, Universitas, Yogyakarta

\section{Statistical analysis}

Statistical analysis was done using SPSS Statistics 20. Univariate analysis was performed on numerical data and was shown as mean or median, while categorical data was displayed in proportion. Chi-square or Fisher's exact tests were used to compare independent and dependent variables, with relative risk as a measure of the strength of the relationship. Statistical significance was defined to be $p<0.05$. Multivariate analysis was performed using logistic regression.

\section{RESULTS}

Fifty-eight IVF infants were initially screened for this study, but three infants were excluded due to their IVF not having been performed in Dr. Sardjito General Hospital and one due to loss of the medical records. Hence, 54 subjects were included in the IVF group. No infants born from natural pregnancies were excluded, for a total of 54 naturally conceived subjects (FIGURE 1).

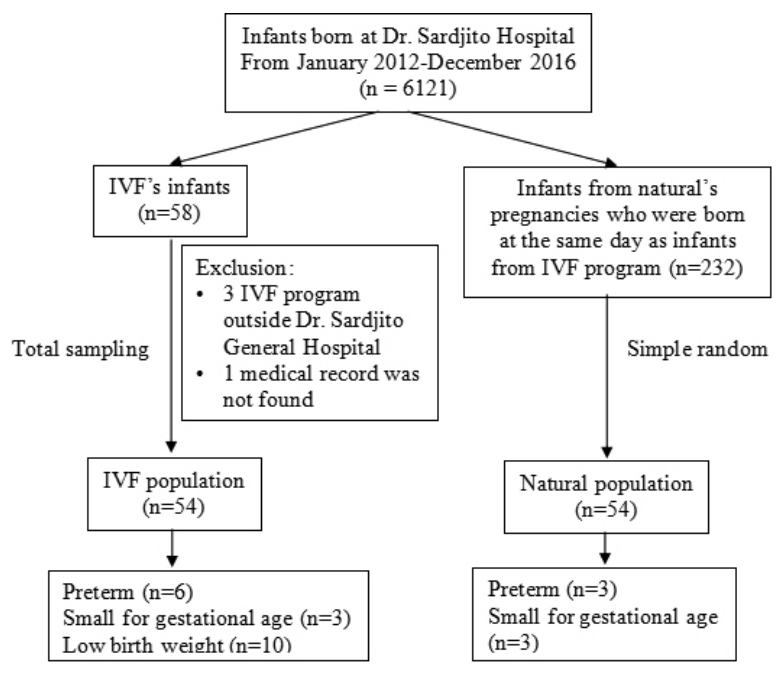

FIGURE 1. Flowchart of subjects recruitment

The characteristics of subjects are shown in TABLE 1 . The IVF group $(88.9 \%)$ had a greater proportion of parity 0 (nulliparous) than the natural group (38.9\%). In addition, the IVF group $(22.2 \%)$ had a greater proportion of multiple pregnancies than the natural group $(7.40 \%)$, though the proportion of singletons $(77.8 \%)$ was still greater than the proportion of multiples $(22.2 \%)$ in the IVF group. Moreover, the IVF group (92.6\%) had a greater proportion of caesarean section deliveries than the natural group (48.1\%). 
TABLE 1. Characteristics of IVF and naturally conceived subjects

\begin{tabular}{|c|c|c|}
\hline Characteristics & $\begin{array}{c}\text { IVF } \\
(n=54)\end{array}$ & $\begin{array}{l}\text { Natural } \\
(n=54)\end{array}$ \\
\hline \multicolumn{3}{|l|}{ Maternal age $[\mathrm{n}(\%)]$} \\
\hline - 20-34 years & $34(63.0)$ & $36(66.7)$ \\
\hline$\cdot \geq 35$ years & $20(37.0)$ & $18(33.3)$ \\
\hline Maternal age (mean \pm SD years) & $33.2 \pm 3.74$ & $31.4 \pm 5.53$ \\
\hline \multicolumn{3}{|c|}{ Parity prior to this pregnancy $[\mathrm{n}(\%)]$} \\
\hline • 0 & $48(88.9)$ & $21(38.9)$ \\
\hline$\cdot \geq 1$ & $6(11.1)$ & $33(61.1)$ \\
\hline \multicolumn{3}{|l|}{ Gestational age, $\mathrm{n}(\%)$} \\
\hline - Full term & $48(88.9)$ & $51(94.4)$ \\
\hline - Preterm & $6(11.1)$ & $3(5.60)$ \\
\hline \multicolumn{3}{|l|}{ Number of fetuses $[\mathrm{n}(\%)]$} \\
\hline - Single & $42(77.8)$ & $50(92.6)$ \\
\hline - Multiple & $12(22.2)$ & $4(7.40)$ \\
\hline \multicolumn{3}{|l|}{$\operatorname{Sex}[\mathrm{n}(\%)]$} \\
\hline - Male & $27(50.0)$ & $34(63.0)$ \\
\hline - Female & $27(50.0)$ & $20(37.0)$ \\
\hline \multicolumn{3}{|l|}{ Birth weight, n (\%) } \\
\hline - Normal & $44(81.5)$ & $46(85.2)$ \\
\hline - Low & $10(18.5)$ & $8(14.8)$ \\
\hline $\begin{array}{l}\text { Birth weight } \\
{[\text { median }(\text { min-max }) / \text { mean }(\mathrm{SD})]}\end{array}$ & $\begin{array}{c}2,875.0 \\
(600-3850)\end{array}$ & $\begin{array}{c}2,928.4 \\
(400)\end{array}$ \\
\hline \multicolumn{3}{|c|}{ Birth weight for gestational age, $\mathrm{n}(\%)$} \\
\hline - AGA & $51(94.4)$ & $51(94.4)$ \\
\hline - SGA & $3(5.60)$ & $3(5.60)$ \\
\hline \multicolumn{3}{|l|}{ Mode of delivery [n (\%)] } \\
\hline - Vaginal & $4(7.4)$ & $28(51.9)$ \\
\hline - Caesarean section & $50(92.6)$ & $26(48.1)$ \\
\hline Placental abnormalities, n (\%) & $4(7.4)$ & $0(0)$ \\
\hline
\end{tabular}

$\mathrm{AGA}=$ appropriate for gestational age; $\mathrm{SGA}=$ small for gestational age

TABLE 2 shows the bivariate analysis between the independent variables and preterm. The IVF infants had two times the risk of preterm birth than natural infants. However, it was not significantly different $(95 \%$ CI 0.52 -
7.58; $\mathrm{p}=0.48$ ). Other independent variables such as maternal age, parity, and placental abnormalities had no significantly association with the occurrence of preterm birth $(\mathrm{p}>0.05)$. 
TABLE 2. Bivariate analysis of independent variables and preterm

\begin{tabular}{|c|c|c|c|c|c|}
\hline Variables & $\begin{array}{c}\text { Preterm } \\
(n=9)\end{array}$ & $\begin{array}{l}\text { Full term } \\
(n=99)\end{array}$ & $\mathbf{R R}$ & $\begin{array}{c}\text { Bivariate } \\
95 \% \text { CI }\end{array}$ & $\mathbf{p}$ \\
\hline $\begin{array}{l}\text { Fertilization process }[\mathrm{n}(\%)] \\
\text { - IVF } \\
\text { - Natural }\end{array}$ & $\begin{array}{c}6(11.1) \\
3(5.6)\end{array}$ & $\begin{array}{l}48(88.9) \\
51(94.4)\end{array}$ & 2.0 & $0.52-7.58$ & 0.48 \\
\hline $\begin{array}{l}\text { Maternal age }[\mathrm{n}(\%)] \\
\cdot 20 \text { - } 34 \text { years } \\
\cdot \geq 35 \text { years }\end{array}$ & $\begin{array}{c}5(7.1) \\
4(10.5)\end{array}$ & $\begin{array}{l}65(92.9) \\
34(89.5)\end{array}$ & 0.67 & $0.19-2.37$ & 0.71 \\
\hline $\begin{array}{l}\text { Parity prior to pregnancy }[\mathrm{n}(\%)] \\
\text { - Nulliparous } \\
\text { - Multiparous }\end{array}$ & $\begin{array}{l}6(8.7) \\
3(7.7)\end{array}$ & $\begin{array}{l}63(91.3) \\
36(92.3)\end{array}$ & 1.13 & $0.29-4.27$ & 1.00 \\
\hline $\begin{array}{l}\text { Placental abnormalities }[\mathrm{n}(\%)] \\
\text { - Yes } \\
\text { - No }\end{array}$ & $\begin{array}{l}1(25) \\
8(7.7)\end{array}$ & $\begin{array}{c}3(75) \\
96(92.3)\end{array}$ & 3.25 & $0.52-20.1$ & 0.29 \\
\hline
\end{tabular}

Bivariate analysis of the independent variables and SGA revealed no increased risk of SGA in IVF infants $(\mathrm{RR}=1.0 ; 95 \% \mathrm{CI}$ 0.21- 4.73; $\mathrm{p}=1.0)$. Other independent variables such as maternal age, parity, and placental abnormalities also had no significant association with the incidence of SGA (TABLE 3).

TABLE 3. Bivariate analysis of independent variables and SGA

\begin{tabular}{|c|c|c|c|c|c|}
\hline Variable & $\begin{array}{l}\text { SGA } \\
(n=6)\end{array}$ & $\begin{array}{c}\text { AGA } \\
(n=102)\end{array}$ & RR & $\begin{array}{c}\text { Bivariate } \\
95 \% \mathrm{CI}\end{array}$ & p \\
\hline $\begin{array}{l}\text { Fertilization process }[\mathrm{n}(\%)] \\
\text { - IVF } \\
\text { - Natural }\end{array}$ & $\begin{array}{l}3(5.6) \\
3(5.6)\end{array}$ & $\begin{array}{l}51(94.4) \\
51(94.4)\end{array}$ & 1.0 & $0.21-4.73$ & 1.0 \\
\hline $\begin{array}{l}\text { Maternal age }[\mathrm{n}(\%)] \\
\cdot 20-34 \text { years } \\
\cdot \geq 35 \text { years }\end{array}$ & $\begin{array}{l}3(4.3) \\
3(7.9)\end{array}$ & $\begin{array}{l}67(95.7) \\
35(92.1)\end{array}$ & 0.54 & $0.11-2.56$ & 0.66 \\
\hline $\begin{array}{l}\text { Parity prior to this pregnancy [n (\%)] } \\
\text { - Nulliparous } \\
\text { - Multiparous }\end{array}$ & $\begin{array}{l}3(4.3) \\
3(7.7)\end{array}$ & $\begin{array}{l}66(95.7) \\
36(92.3)\end{array}$ & 0.56 & $0.12-2.67$ & 0.66 \\
\hline $\begin{array}{l}\text { Placenta abnormalities }[\mathrm{n}(\%)] \\
\text { - Yes } \\
\text { - No }\end{array}$ & $\begin{array}{c}0(0) \\
6(5.80)\end{array}$ & $\begin{array}{c}4(100) \\
98(94.2)\end{array}$ & & & 1.00 \\
\hline
\end{tabular}

$\mathrm{SGA}=$ small for gestational age; $\mathrm{AGA}=$ appropriate for gestational age

Bivariate analysis of the independent variables and LBW revealed that IVF infants had 1.2 times higher risk of LBW compared to naturally conceived infants. However, it was was not significantly different $(95 \% \mathrm{CI} 0.53$
- 2.92; $p=0.6$ ). Other independent variables such as maternal age, parity, and placental abnormalities were not also significantly associated with LBW incidence (TABLE 4). 
TABLE 4. Bivariate analysis of independent variables and LBW

\begin{tabular}{|c|c|c|c|c|c|}
\hline Variable & $\begin{array}{c}\text { LBW } \\
(n=18)\end{array}$ & $\begin{array}{c}\text { NBW } \\
(n=90)\end{array}$ & $\mathbf{R R}$ & $\begin{array}{c}\text { Bivariate } \\
95 \% \mathrm{CI}\end{array}$ & p \\
\hline $\begin{array}{l}\text { Fertilization process }[\mathrm{n}(\%)] \\
\text { - IVF } \\
\text { - Natural }\end{array}$ & $\begin{array}{c}10(18.5) \\
8(14.8)\end{array}$ & $\begin{array}{l}44(81.5) \\
46(85.2)\end{array}$ & 1.25 & $0.53-2.92$ & 0.60 \\
\hline $\begin{array}{l}\text { Maternal age }[\mathrm{n}(\%)] \\
\cdot 20-34 \text { years } \\
\cdot \geq 35 \text { years }\end{array}$ & $\begin{array}{c}10(14.3) \\
8(21.1)\end{array}$ & $\begin{array}{l}60(85.7) \\
30(78.9)\end{array}$ & 0.67 & $0.29-1.57$ & 0.37 \\
\hline $\begin{array}{l}\text { Parity prior to pregnancy }[\mathrm{n}(\%)] \\
\text { - Nulliparous } \\
\text { - Multiparous }\end{array}$ & $\begin{array}{c}11(15.9) \\
7(17.9)\end{array}$ & $\begin{array}{l}58(84.1) \\
32(82.1)\end{array}$ & 0.88 & $0.37-2.10$ & 0.78 \\
\hline $\begin{array}{l}\text { Placenta abnormalities }[\mathrm{n}(\%)] \\
\text { - Yes } \\
\text { - No }\end{array}$ & $\begin{array}{c}1(25) \\
17(16.3)\end{array}$ & $\begin{array}{c}3(75) \\
87(83.7) \\
\end{array}$ & 1.53 & $0.26-8.82$ & 0.52 \\
\hline
\end{tabular}

LBW: low birth weight; NBW: normal birth weight

Multivariate analysis could not be performed in this study due to no variables had $\mathrm{p}$ values $<0.25$ after bivariate analysis performed.

\section{DISCUSSION}

The proportions of preterm infants were $11.1 \%$ and $5.6 \%$ in the IVF and natural groups, respectively. Similarly, a previous study reported that the prevalence of preterm ranged from 7.8 to $16.1 \%$ in IVF population and $4.5 \%$ to $8.0 \%$ in natural population. ${ }^{14}$ Nevertheless, no significant association between IVF and preterm $(p=0.48)$ was observed, whereas several previous studies showed significant results. ${ }^{14,15}$ Koivurova et $a l .{ }^{16}$ found no significant association between singleton IVF and preterm (OR 1.5; 95\% CI 0.7 - 3.2), in which the control was only singleton pregnancies taken from the general population. However, this result became significant when both singleton and multiple pregnancies were taken as control subjects (OR 5.6; 95\%CI 3.7 8.6). As such, sample diversity is an important factor in the incidence of preterm. ${ }^{16}$
All infants from ART procedures may be predisposed to preterm birth. Previous studies divided ART into subgroups, i.e., fresh with frozen embryos, oocyte donors with own oocytes, standard IVF with intracytoplasmic sperm injection (ICSI), and third day with fifth day embryo showed greater risk of preterm, LBW and VLBW in each subgroup. ${ }^{17,18}$ Maternal morbidity and mortality among Swedish women giving birth after in vitro fertilisation (IVF) However, Romundstad et al. ${ }^{19}$ also compared natural conception with ART in the same mothers and found no significant difference. They concluded that ART did not harm the perinatal outcome, but genetics was more likely to be an underlying factor of preterm incidence. Another study mentioned that ART pregnancies were generally more closely monitored, such that birth was more frequently subject to induction and caesarean section. These ART interventions also have been associated with SGA incidence, increased perinatal mortality, and VLBW. ${ }^{14}$

The proportion of SGA in our study was similar in both the IVF and natural groups 
$(5.6 \%)$. Previous studies reported SGA in $12.7 \%$ of IVF pregnancies and $13 \%$ of natural pregnancies, ${ }^{20}$ and $2.89 \%$ in both IVF and natural newborns. ${ }^{21}$ In this study, there was no increased risk of SGA in IVF infants. However, this finding may not be conclusive, as a previous meta-analysis stated that the risk of SGA in IVF pregnancies was 1.3 times higher compared to natural pregnancies $(95 \% \mathrm{CI} 1.27$ to 1.53$).{ }^{22}$ In contrast, other studies stated that there was no increased risk of SGA in IVF infants. ${ }^{20,21,23}$ Wen et al. ${ }^{23}$ noted that general and more diverse populations tended to have significant influences on SGA incidence.

The proportions of LBW in our study were $18.5 \%$ and $14.8 \%$ in the IVF and natural groups, respectively. Similarly, a previous study reported LBW of $11.2 \%$ in IVF and $11.6 \%$ in natural newborns. ${ }^{20}$ Our bivariate analysis revealed no significant association between IVF and LBW incidence $(\mathrm{p}=0.60)$, similar to previous studies that compared LBW and preterm in ART and non-ART groups. ${ }^{20,24}$ In contrast, a recent meta-analysis suggested that LBW tended to occur in the IVF population compared to the natural population, even if the baby is full term. ${ }^{25}$ Differences in the size of the research scale may explain our lack of association between IVF and LBW, as small-scale research tended to get no significant results. ${ }^{20}$

Placental abnormalities (all placenta previa) were only found in our IVF group $(7.4 \%)$, but there were not significantly different from the natural population. IVF procedures such as cervical catheterization, or mechanically- inducing uterine contractions may play a major role in implantation in the lower uterine segment, thus leading to placenta previa. ${ }^{19}$ Another study explained that high concentrations of estradiol hormone in the IVF cycle increased complications associated with placental aberration by affecting endometrial growth and decidualization. ${ }^{26}$

Several previous studies have noted that the underlying factors of preterm, SGA, and LBW remain unclear. ${ }^{7,27,28}$ To date, the underlying factors are maternal age, infertility/ subfertility, genetics, as well as the IVF technique itself, but we were unable to assess for these variables in our study. Furthermore, women who undergo ART may differ from the general population, as these women usually have high socioeconomic status, good nutritional status, better antenatal care, and sufficient rest during pregnancy. These factors are believed to positively affect pregnancy and its outcome. ${ }^{24}$ Another study reported that most pregnancies from the IVF program had no complications and resulted in the birth of healthy babies. ${ }^{29}$

Several limitations of our study should be noted. The small and potentially inadequate sample size as well as the retrospective study design may have led to information bias. The selection of no intervention populations (natural populations) appropriate to the IVF population WAS also a weakness. Women who underwent IVF treatment in this study generally had middle to upper economic status (because the IVF program in Indonesia is not guaranteed by insurance), more routine control, consultation, and treatment during pregnancy, especially by the obstetrician. Hence, the IVF group may have received better attention and care than the natural group. Another weakness in our study was that some important variables such as socioeconomic status and maternal education were not recorded completely in the medical records, so they were not included in the analysis.

\section{CONCLUSION}

In conclusion, the risk of preterm birth and LBW in IVF infants tend to be higher than 
in naturally conceived infants. However, they are not statistically significant. In addition, there is no increased risk of SGA in IVF infants. Further research using a larger sample size is needed for more representative data of the actual conditions in the population.

\section{ACKNOWLEDGMENTS}

We would like to thank Permata Hati Infertility Clinic, Dr. Sardjito General Hospital, Yogyakarta for contributing to this study.

\section{REFERENCES}

1. Egbe TO, Sandjon G, Ourtchingh C, Simo A, Priso EB, Benifla J-L. In vitro fertilization and spontaneous pregnancies: matching outcomes in Douala, Cameroon. Fertil Res Pract 2016; 2: $1-8$. https://doi.org/10.1186/s40738-015-0013-2

2. Indonesia Association In Vitro Fertilization. Understanding access to ART in Indonesia. 2012. [serial online] [cited $2015 \mathrm{Feb}$ 12]. Availale from : http://www.ia-ifv.org/?p=33

3. Ramalingam M, Durgadevi $\mathrm{P}$, Mahmood T. In vitro fertilization. Obstet Gynaecol Reprod Med 2016; 26: 200-9. https://doi.org/10.1016/j.ogrm.2016.05.006

4. Allen VM, Wilson RD, Cheung A. Pregnancy outcomes after assisted reproductive technology. J Obstet Gynaecol Canada 2006; 28: $220-50$.

https://doi.org/10.1016/S17012163(16)32112-0

5. Gao L, Yang S. Perinatal outcomes of children born after assisted reproduction technology: a review. Austin J Reprod Med Infertil 2015; 2: $1-3$.

6. Klemetti R, Sevón T, Gissler M, Hemminki E. Health of children born as a result of in vitro fertilization. Pediatrics 2006; 118: 1819-27. https://doi.org/10.1542/peds.2006-0735
7. Voorhis BJ Van. In Vitro Fertilization. N Engl J Med 2007; 356: 379-86. https://doi.org/10.1056/NEJMcp065743

8. Chou H, Tsao P, Yang Y, Tang J, Tsou K. Neonatal outcome of infants born after in vitro fertilization at National Taiwan University Hospital. J Formos Med Assoc 2002; 101: 203-5.

9. Gupta P, Nayan N, Sharma M. Perinatal outcomes among children born by assisted reproductive techniques-a hospital-based case control study. Med J Armed Forces India 2012; 68: 132-5.

https://doi.org/10.1016/S037 71237(12)60019-7

10. Soebijanto S. Prediction of pregnancy success rate through in vitro fertilization based on maternal age. Med J Indones 2009; 18: 244-8. https://doi.org/10.13181/mji.v18i4.371

11. Klinik Permata Hati. Format laporan program TRB (Teknologi Reproduksi Berbantu). Yogyakarta: Klinik Permata Hati-RSUP Dr. Sardjito: Yogyakarta, 2014.

12. Klinik Permata Hati. Format laporan program TRB (Teknologi Reproduksi Berbantu). Yogyakarta: Klinik Permata Hati-RSUP Dr. Sardjito: Yogyakarta, 2015.

13. Smith V. The high-risk newborn: anticipation, evaluation, management, and outcome. In: Cloherty J, Eichenwald E, Hansen A, Stark A editors. Manual of neonatal care. Philadelphia: Lippincot Williams \& Wilkin: Philadelphia, 2012.

14. Šljivančanin T, Kontić-vučinić O. Perinatal outcomes of pregnancies conceived by assisted reproductive technologies. Srp Arh Celok Lek 2015; 143: 632-8. https://doi.org/10.2298/SARH1510632S

15. Frangez HB, Korosec S, Verdenik I, Kotar V, Kladnik U, Bokal EV. Preterm delivery risk factors in singletons born after in vitro fertilization procedures. Eur J Obstet Gynecol 2014; 176: 183-6. https://doi.org/10.1016/j.ejogrb.2014.03.002 
16. Koivurova S, Hartikainen A, Gissler M, Hemminki E, Sovio U, Jarvelin M. Neonatal outcome and congenital malformations in children born after in vitro fertilization. Hum Reprod 2002; 17: 1391-8. https://doi.org/10.1093/humrep/17.5.1391 https://doi.org/10.1093/humrep/17.11.3005

17. Källén B, Finnström $\mathrm{O}$, Nygren KG, Otterblad Olausson P, Wennerholm UB. In vitro fertilisation in Sweden: obstetric characteristics, maternal morbidity and mortality. BJOG 2005; 112: 1529-35.

https://doi.org/10.1111/j.14710528.2005.00745.x

18. Schieve L, Cohen B, Nannini A, Ferre C, Reynolds M, Zhang Z. Massachusetts Consortium for Assisted Reproductive Technology Epidemiologic Research (MCARTER). A populationbased study of maternal and perinatal outcomes associated with assisted reproductive technology in Massachusetts. Matern Child Heal J 2007; 11: 517-25.

https://doi.org/10.1007/s10995-007-0202-7

19. Romundstad L, Romundstad P, Sunde A, V von D, Skjaerven R, Gunnell D. Effects of technology or maternal factors on perinatal outcome after assisted fertilisation: a population-based cohort study. Lancet 2008; 372: 737-43.

https://doi.org/10.1016/S01406736(08)61041-7

20. Reubinoff BE, Samueloff A, Ben-Haim M, Friedler S, Schenker JG, Lewin A. Is the obstetric outcome of in vitro fertilized singleton gestations different from natural ones ? a controlled study. Fertil Steril 1997; 67: 1077-83.

https://doi.org/10.1016/S00150282(97)81442-2

21. Isaksson R, Gissler M, Tiitinen A. Obstetric outcome among women with unexplained infertility after IVF: a matched case-control study. Hum Reprod 2002; 17: 1755-61. https://doi.org/10.1093/humrep/17.7.1755

22. Pandey S, Shetty A, Hamilton M, Bhattacharya S, Maheshwari A. Obstetric and perinatal outcomes in singleton pregnancies resulting from ivf/icsi: A systematic review and metaanalysis. Hum Reprod Update 2012; 18: 485503.

https://doi.org/10.1093/humupd/dms018

23. Wen S, Leader A, White R, Leveille M, Wilkie $\mathrm{V}$, Zhou J et al. A comprehensive assessment of outcomes in pregnancies conceived by in vitro fertilization/intracytoplasmic sperm injection. Eur J Obs Gynecol Reprod Biol 2010; 150: 160-5. https://doi.org/10.1016/j.ejogrb.2010.02.028

24. Fitzsimmons BP, Bebbington MW, Fluker MR. Perinatal and neonatal outcomes in multiple gestations: Assisted reproduction versus spontaneous conception. Am J Obs Gynecol 1998; 179: 1162-7.

https://doi.org/10.1016/S00029378(98)70125-5

25. Bruggeman JW. The effect of in vitro fertilization on low birth weight and preterm delivery in Singletons : a brief review and meta-analysis. Hum Body 2016; 1: 40-5.

26. Farhi J, Ben-Haroush A, Andrawus N, Pinkas H, Sapir O, Fisch B. High serum oestradiol concentrations in IVF cycles increase the risk of pregnancy complications related to abnormal placentation. Reprod BioMed Online 2010; 21: 331-7. https://doi.org/10.1016/j.rbmo.2010.04.022

27. Jackson RA, Gibson KA, Wu YW, Croughan MS.Perinatal outcomes in Singletons following in vitro fertilization : a meta analysis. Am Coll Obstet Gynecol 2004; 103: 551-63. ht tps://doi.org/10.1097/01. AOG.0000114989.84822.51

28. Royal College of Obstetricians and Gynaecologist. In vitro fertilisation : perinatal risks and early childhood outcomes. Sci Impact Pap 2012; 8:1-12. 
29. Okun N, Sierra S, Wilson RD, Audibert F, Brock J-A, Campagnolo $\mathrm{C}$ et al. Pregnancy outcomes after assisted human reproduction.
J Obstet Gynaecol Canada 2014; 36: 64-83. https://doi.org/10.1016/S17012163(15)30685-X 